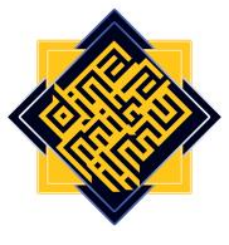

\title{
Analysis of Grammatical Cohesion in Qira'at Text (The Reading) of Al-Arabiya Baina Yadaik li Book
}

\author{
Mohammad Ahsanuddin \\ Arabic Literature Department, Faculty of Letter, Universitas Negeri Malang \\ e-mail:mohammad.ahsanuddin.fs@um.ac.id \\ Ali Ma'sum \\ Arabic Literature Department, Faculty of Letter, Universitas Negeri Malang
}

Abstract

This study aims to describe referential devices, substitution ellipsis, and conjunction in qira'at (the reading) text of Al-Arabiya Baina Yadaik (ABY) II book. This research uses a qualitative method in an appropriate setting with a grammatical cohesion analysis approach to identify the grammatical elements from a reference perspective within the qira'at text in the ABY II book. The obtained data subsists of grammatical cohesion, including referential devices, substitution, ellipsis, and conjunction in qira'at (the reading) text. Due to the limited research time, there were only eight qira'at texts, from wihdah (unit) 1-8 of the $A B Y$ II book, explored in this research. The results indicate that (1) the referential devices in the qira'at texts is personal (subsisting of third-person singular 'mufrad', dual 'mutsanna', and plural), demonstrative ( the word ذلك and comparative (the words that compare sentences); (2) the identified substitution devices are nominal and clause substitution; (3) the discovered ellipsis devices are nominal, verbal and clause ellipsis; and (4) the found conjunction devices are temporal, causal, additive, and adversative.

Keywords: conjunction, grammatical cohesion, reference, substitution ellipsis 


\section{A. Introduction}

Language acquires a substantial role for humans in communicating with their surrounding society. It always presents in human's daily life, as their means to express an idea, thought, opinion, and feeling. Language appears as the most critical medium to articulate those needs. In their daily communication, humans use language as maximum as possible to attain the desired communication. Besides, language is also closely related to discourse. Through a language, discourse can be the object of reflection and expression of someone's feelings. Soeparno (2002:1) describes language as an arbitrary system of the sound pattern used by a member of society to corporate, interact, and identify themselves.

Discourse is part of language embodiment as the writer's inspiration to communicate their ideas. Besides, the close relationship between language and discourse appears because discourse can serve as a voice of feelings and reflection for the writer. The language participants realize interaction and social communication through an excellent written and spoken discourse. Perfect and proper discourses prohibit misunderstanding among language participants.

In addition, discourse is the complete spoken language unit. The examples of spoken discourse are speech, lecture, sermon, and dialog. Meanwhile, the examples of written discourse are novels, short stories, letters, books, and written documentation. Thus, the qira'at (reading) text in Al-Arabiyah Baina Yadaik (ABY) is also one of the discourse forms.

Al-Arabiya Baina Yadaik (ABY) book is an Arabic learning book for the non-Arab learner. This book has three volumes for beginner, intermediate, and advanced learners. Each work is also equipped by recording files for both teacher and learner. Many Islamic Universities in Indonesia use this book in their Arabic learning.

$A B Y$ book is developed with excellent systematic learning that facilitates the learner to study and comprehend Arabic easily. The book aims to help the learner to master the language, communication, and cultural-understanding skill. In relation to language ability, all language skills are provided in the book, including the qira'at (reading) skills.

The texts investigated in this study are qira'at (reading) text in ABY II books since (1) students are familiar with some vocabularies from ABY I book, (2) students have recognized types of Arabic sentences, and (3) students have known Arabic punctuation marks. As a discourse, the texts consist of words, phrases, clauses, and sentences that form cohesive and complete information. In the writing process of a discourse, the use of cohesive devices that is semantically related to discourse elements should be considered.

The association of sentences in a discourse can be carried out through devices or mediums; one of them is grammatical cohesion. Mulyana (2005:26) mentions that grammatical cohesion is a discourse element that consists of intact and stable linkages of words or sentences. At the same time, the grammatical cohesion components include reference, substitution, ellipsis, and conjunction.

Some principles should be regarded in comprehending a discourse text. Those principles are unity and coherent. In other words, the fundamental point of discourse is clauses or sentences that express careful thought. A discourse should possess coherent information and comprehensible supporting elements. A coherent discourse is cohesive if 
it is seen from the relation of form or structure and coherent if it is seen from the association of meaning or structure. A complete discourse has sentences that promote a topic, while a cohesive discourse has systematically arranged sentences that present a coherent idea marked by coherent devices.

From the aforementioned information, the elements that formulate discourse cohesion should be continuous and form a single text structure. An unclear sequence of progression creates an ambiguous and incoherent discourse. Besides, statements with an obscure order are not a discourse. The cohesiveness of discourse is essential since it upholds its coherence. Halliday \& Hasan (1992: 65) explain that the necessary assistance for a coherent discourse comes from cohesion, the language source devices of every language that function as textual metafunction to correlate every part of the text.

In addition, the coherence of discourse is also realized through the situational context, outside the language formality aspect. Halliday \& Hasan (1992: 66) state that every part of the text manifests the meaning and the context of the text; thus, we all have to be aware of those functions.

Contextual understanding is essential in discourse since text and context are in one unity that cannot be detached. Context can differentiate the discourse that is used as the language used in communication, and those used not for communication purposes. It is also supported by Halliday \& Hasan (1976: 20), that a text cannot be evaluated with no information on its situational context.

Another similar study has been conducted by Aimanah (2016), entitled "Cohesion and Coherence of Arabic Reading Text from Ministry of Religion Book for 10 Grade Senior High School Students and Its Impacts on Arabic Learning." That research finds excellent cohesiveness from a cohesive and coherent perspective within the Arabic textbook for 10 grades from the Ministry of Religion. It is demonstrated from the realization of cohesive and coherent elements in the five texts being investigated.

Besides, Wiyanti (2016) conducts research entitled "Analysis of Grammatical Cohesion Substitution and Ellipsis on 'Laskar Pelangi' Novel by Andrea Hirata." This study reveals uneven usage of language elements, such as sentence, phrase, clause, and sentence, as a referrer for two paired sentences.

Another study has also been carried out by Zulaiha (2014) on the grammatical and lexical cohesion in Jemini novel by Saparto Brata. The results indicate that grammatical cohesion markers found are reference, including personal reference I, II, and II; demonstrative reference of time and place; comparative reference; substitution; ellipsis; and conjunction, involving coordinative, subordinative, sequence, additional, consensive, clause, optional, time, contradiction, purpose, and exceptional conjunction. At the same time, the lexical cohesion marker found includes epizeukis and anadiplosis repetition, synonym, antonym, hyponymy, and equivalences.

There are similarities and differences among those previous studies and this study. The similarity is in the theoretical framework used, the grammatical cohesion. Meanwhile, the difference is in the object being investigated. Therefore, this study entitled "Analysis of 
Grammatical Cohesion on Qira'at (Reading) Texts in Al-Arabiyah Baina Yadaik II" was carried out.

\section{B. Research Methodology}

This research uses qualitative or ethnographic methods (Bogdan \& Biklen, 1982:2-3) in an appropriate setting with a grammatical cohesion analysis approach to reveal the grammatical elements from a reference perspective within qira'at texts in the ABY II book. The instrument used in the data collection process was the researchers, as it used a qualitative approach. The researchers, as the key instrument, reveal the grammatical cohesion devices, including reference, substitution, ellipsis, and conjunction in qira'at (reading) text in the $A B Y$ II book. Further, the researcher in this qualitative study also planned, collected the data, analyzed the data, interpreted the data, and reported the research results (Moleong,1998: 121).

The data was obtained to solve the research problems in the form of grammatical cohesion devices that subsist of reference, substitution, ellipsis, and conjunction in qira'at (reading) text. Due to the limited time, only eight qira'at texts, from wihdah (unit) 1-8 from the ABY II book are being investigated. In this qualitative research, the data was obtained through document analysis to find grammatical cohesion devices, including reference, substitution, ellipsis, and conjunction within the qira'at (reading) text. The already seen grammatical cohesion was noted in a table specially prepared for this process so that the data can be easily read.

Data analysis in this research was carried out along with the data collection process. The analysis model was adapted from Miles et.al, consisting of (1) data condensation, (2) data presentation, and (3) drawing conclusion (2014). The analysis process was conducted circularly. In other words, after the conclusion is made, another data collection process can be carried out until a valid and similar finding is made. Thus, in the initial process, the researcher made open hypothesizes to be confirmed through relevant data being analyzed in the next step. This way, research results that fulfill particular validity requirements (transferability and dependability) can be obtained. The researchers used some techniques to obtain valid data and results. First, the researcher conducted a research extension, two days a week, for six months. Second, the data was analyzed continuously and systematically. Third, the researchers carried a discussion with colleagues who are experts in the research contents and methodology. Fifth, the researchers analyzed negative cases. Lastly, an assessment of reference adequacy, both in literal reference and subject action, was conducted.

\section{Findings}

In this research, eight qira'at texts from ABY II books, units 1 to 8, were selected. Due to the limited time, only one text was chosen from each unit. The title of those texts is زينب الماذا يفضل بعض الناس الحياة في المدن الكبيرة؟ هل تحدث مشكلات بين الزوجين ,أنواع الترويح ,ومريم صديقتان

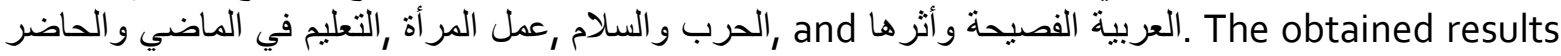


from grammatical cohesion analysis within qira'at (reading) text in Al-Arabiyah Baina Yadaik II book are explained below.

\section{Referential Devices in Qira'at Texts in ABY II Book}

Reference is one of the grammatical cohesion devices. Halliday \& Hasan (1976: 89) mentions that reference is the relation between meanings within the linguistic system in grammatical steps. Reference (إحالة) is a symbol that point to particular language element located before or after the reference. There are three types of reference cohesion, namely, personal, demonstrative, and comparative.

\section{a. Personal Reference}

According to Emzir (2011: 13), a personal reference is stated by the pronoun and determinator that function to show an individual or object mentioned within the text. Besides, Alwi et al. (2000: 249) mention that a personal pronoun is a pronoun used to refer to a person. This pronoun can point to one-self (first personal pronominal), the people someone talks to (second personal pronominal), and the person being spoken of (third personal pronominal). From the analysis results obtained on units 1 and 5 , the obtained data is:

$$
\begin{aligned}
& \text { 1- زينب ومريم صديقتان، تتشابهان في أشياء كثيرة، فهما تسكنان في حي واحد }
\end{aligned}
$$

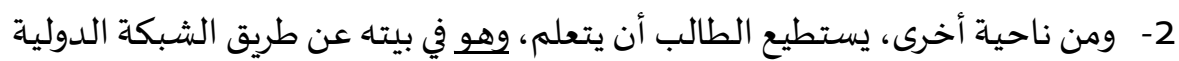

In the first (1) sentence, فهما word that refers to Zainab and Maryam. Data (1) has a third personal pronominal. This third personal pronoun in a cataphoric manner refers to the constituent in the prior words, Zainab and Maryam. Meanwhile, on (2) sentence, the word الطالب is refers to the word. Pو is the third-person singular pronoun.

In Indonesian, the personal pronoun is only classified into a singular (mufrad) and plural (jama'); there is no second (mutsanna) personal pronoun. Therefore, the expression of the third personal pronoun, two people use the word "they" is added with "both of them," the synonym of "they" that is commonly used for III personal pronouns.

The third Los and second s personal pronoun can be appropriately interpreted if they are linked to the previous sentence. Based on that relation among sentence in the discourse, the pronoun هo and are anaphorically referred to Zainab and Maryam for and الطالب for هو

The relation between هو ها هith Zainab and Maryam, along with الطالب makes the discourse has definite and reinforcing meaning.

\section{b. Demonstrative Reference}

Demonstrative reference cohesion is symbolized by determinator and adverb that function as an indication of text elements, from a location perspective (Emzir, 2011:13). Within the $A B Y$ II book, several points were obtained in relation to demonstrative reference in the units, as explained below":

Dinamika Ilmu, Volume 21(2), 2021 


$$
\text { 1- لم تمارس زينب الرياضية، ورغم ذلك ظلت نحيفة }
$$

In the (1) sentence, the word ذلك "that" is anaphorically referred to as the previous sentence. The demonstrative pronoun ذلك is placed after the overlooked sentence and operates as an affirmation. It affirms that Zainab does not do exercises, but she is still thin.

\section{c. Comparative Reference}

Comparative reference is marked by adjectives and adverbs that operate to compare elements from an identity and similarity perspective (Emzir, 2011: 13). The comparative reference data found in the $A B Y$ II book is:

$$
\text { فزينب نحيفة جدا، ومريم سيمنة جدا }
$$

Within the above sentence, there is the word نحيفة "skinny" for Zainab and سمينة "plump" for Maryam. Meanwhile, another sentence with comparative reference is also found in unit 5 .

$$
\begin{aligned}
& \text { كان طلاب العلم - في الماضي - يسافرون من بلد إلى بلد، لطلب العلم، وكانوا يواجهون في سفرهم كثيرا من }
\end{aligned}
$$

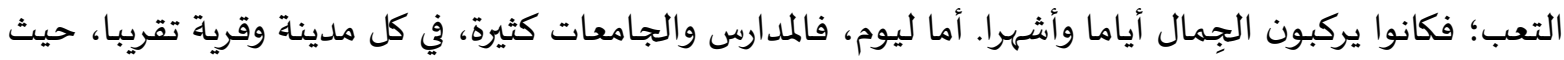

$$
\begin{aligned}
& \text { يذهب الطالب إلى مدرسته، أو جامعتاه بالسيارة، أو سيرا على الأقدام. ومن ناحية أخرى، يستطيع الطالب أن يتعلم، } \\
& \text { وهو في بيته عن طريق الشبكة الدولية. }
\end{aligned}
$$

The text explains a comparison between learners in the previous and recent eras. The writer contrasts that learners in ancient times walked from one to other cities that required a long period and carried extreme exhaustion. However, in the recent era, each city and village has a lot of schools and universities. Thus, learners no longer need to walk far away.

Another form of comparative reference is using the "كلى" device, as also found in Unit 5 , العلم كالماء و الهو اء. It means 'knowledge is similar to water and air. The word compares between knowledge and the air.

\section{Substitution Devices in Qira'at Text of ABY II Book}

Halliday (1981) in Nunan (1987: 6) combines the explanation of substitution and ellipsis since this two cohesion is basically similar. Ellipsis is perceived as a part of substitution that replaces the original form with the empty form. There are three types of substitution and ellipsis, namely nominal, verbal, and clause substitution or ellipsis.

a. Nominal Substitution

$$
\text { يعيش في المدن الكبيرة، مثل: طوكيو.ولندن، ونيويورك والقاهرة }
$$

The word المدن الكبيرة "big cities" in the sentence above represents big cities, such as Tokyo, London, New York, and Egypt.

b. Clause Substitution

$$
\text { في الحياة الزوجية خير كثير للزوجة وللأولاد. ومع ذلك تظهر }
$$

The word ذللك "they are all" in a sentence (2) refers to the previous sentence. 


\section{Ellipsis Devices in Qira'at Text of ABY II Book}

Essentially, the ellipsis is a remedy by changing the main item with a blank thing (Suwandi, 2008: 133). According to Renkema (2004: 103), the ellipsis is removing or relieving a word or a part of a sentence. The results of data analysis revealed three types of ellipsis that appear in the ABY II book, namely nominal, verbal, and clause ellipsis.

\section{a. Nominal Ellipsis}

Alwi et al. (2000: 415) argue that one of the syntax devices that reduces redundancy is ellipsis. The same unremoved element is called the antecedent of the removed part. The removal of antecedents before the eliminated element is named anaphorical removal; meanwhile, the extraction of antecedents that follow the eliminated element is cataphoric. The identified data related to a nominal ellipsis is mentioned below.

$$
\text { زينب ومريم صبديقتان، تتشاهبان في أشياء كثيرة. }
$$

In the above example, the ellipsis occurs in the sentence that is replaced by the تتشابهان form ofthenominal phrase of زينب ومريم. If the sentence is not modified, then there will be a redundant use of the word زينب ومريم. The writer should have a particular aim for avoiding the subject repetition. This modification is known as anaphoric.

b. Verbal Ellipsis

$$
\text { زينب تفكر كثيرا في هذه المشكلة، ماذا تفعل ؟ وزنها الآن خمسة وخمسون كيلا. }
$$

c. Clause Ellipsis

$$
\text { يحتاج كل إنسان إلى أن يعش في أمن وسلام، ومع ذلك تحدث الحروب في كل مكان من العالم }
$$

\section{Conjunction Devices in Qira'at Text of ABY II Book}

Conjunction is included in cohesion since it indicates a relationship that is only comprehensible if there is a reference to the other part of the text. There are four relations that are identified by conjunction, namely temporal, causal, additive, and adversative. Within the ABY II books, several conjunction devices were found.

\section{a. Temporal Conjunction}

Temporal conjunction is a conjunction that explains a relation among two different occasions. This conjunction possesses a close association with time. It functions to demonstrate the chronology of an event, in order that the sentence can be easily understood. There are two types of temporal conjunction, namely equal and unequal. 
Equal temporal conjunction has the same or equivalent features. It cannot be placed at the beginning or at the end of a sentence; it should be put in the middle. The comparable temporal conjunction data found in the ABY II book are presented below.

$$
\begin{aligned}
& \text { 1- وقد أدركت بعض الدول هذه المشكلة، مشكلة الهجرة من الريف إلى المدينة، فبنت مصانع كثيرة في الريف. } \\
& \text { 2- يفضل كثير من الناس القراءة، ففيها فائدة ومتعاة }
\end{aligned}
$$

In example 1, there is a temporal conjunction ف ف ف chronological order completed by the subject (some countries). At the same time, in example 2, the temporal conjunction ف "because" shows the chronological order of human reading activity. By those two temporal conjunctions, the context of a sentence and its relation with the previous sentence can be easily understood.

\section{b. Causal Conjunction}

Based on kbbi.web.id site, causal means relating or operating as a cause. Causal conjunction is a conjunction that connects two words, phrases, clauses, or sentences with causative relation. In other words, it explains an event that occurs because of an originator. The words 'since' and 'because' are frequently used as a conjunction. The example data for this type of conjunction is presented below.

يزداد سكان المدن كل يوم، لأن سكان الريف يهاجرون إليها.

In the above example, the causal conjunction لأن إلنها. is used as the cause of the previous sentence.

c. Additive Conjunction

Additive conjunction (combination) is a coordinative conjunction that operates to combine two similar words, phrases, clauses, or sentences. The example of this conjunction is and, moreover, besides, and also.

d. Adversative Conjunction

زينب ومريم صديقتان.

Adversative conjunction marks a relation of contradiction or differences. The adversative conjunction identified in the ABY II book is presented below.

$$
\text { وليس الهدف من النرويح قتل الوقت، و إنما الهدف قضاء الوقت في أنشطة مفيدة. }
$$

The aim of refreshing is not to waste time, but to use the time for meaningful activities.

The use of adversative conjunction إنما marks a contrast with the previous sentence.

\section{Discussion}

\section{Reverential Devices in Qira'at Text of ABY II Book}

The reverential devices discovered in the ABY II book are personal, demonstrative, and comparative references. Based on the results of data analysis from the ABY II book, the identified personal reference includes the third person singular (mufrad), second (mutsanna), or plural. 
In Arabic, there is a personal pronoun known as ضمير اسمism dhamir. Ism dhamir is divided into two, a stand-alone word is known as منفصل ضمير dhamir munfasil (separated personal pronoun) and as a suffix placed in a noun, verb, or preposition known as صنصل ضمير dhamir muttasil (attached personal pronoun). The stand-alone personal pronoun is divided by the amount and gender difference, as presented in the table below.

\begin{tabular}{|c|c|c|c|c|}
\hline \multirow{2}{*}{$\begin{array}{l}\text { Personal } \\
\text { Pronoun }\end{array}$} & \multirow[t]{2}{*}{ Gender } & \multicolumn{3}{|c|}{ Number } \\
\hline & & Singular & Dual & Plural \\
\hline First & $\begin{array}{ll}\text { Male and } \\
\text { Female }\end{array}$ & أنـا & & نحن \\
\hline \multirow[t]{2}{*}{ Second } & Male & أنتَ & أنتما & أنتح \\
\hline & Female & أنتتِ & أنتما & أنتن \\
\hline \multirow[t]{2}{*}{ Third } & Male & هو & هol & هم \\
\hline & FEmale & هي & Sol & هن \\
\hline
\end{tabular}

In addition, dhamir muttashil is not a stand-alone personal pronoun. It is attached with other words, such as noun (isim), verb (fi'l), and particle or letter. At the same time, the clitic pronoun (dhamirmuttasil) acts as an object (maf'ulbih), complement, and explanation.

The first and second personal pronouns were not found in the discourse text since the text is not a dialogue. The usage of the personal pronoun in the communication process is the manifestation of a variety of written language. Language variety is divided into written and spoken types of language. This variety belongs to the humane characteristic of a language that represents language function as a spoken communication tool in delivering information. The personal pronoun is frequently found in both spoken and written communication. The usage of this pronoun in spoken communication is exhibited through the direct interaction among speakers. Besides, in written communication, this pronoun is observed in discourse text.

The division of personal pronouns in Arabic is different from its division in Indonesian. In Arabic, the personal pronoun is divided based on the number, person, and gender. In contrast, the personal pronoun in Indonesian is divided into singular and plural. The pronoun found in the discourse text of the ABY II book is third-person singular, dual, and plural, as presented in the example below.

$$
\text { زينب ومريم صديقتان، تتشابهان في أشياء كثيرة، فهما تسكنان في حي واحد }
$$

Substantially, each sentence carries an occasion that involves one or more participants with different semantics (Alwi et al., 2014:341). It shortened and solidified the sentence, Arabic grammar of dhamir (personal pronoun) appears. The personal pronoun is used to shorten statements, such as يتشابهان (they are 'female' similar). Besides, it is also used in imperative sentences that frequently only consisted of the primary verb (Chaer, 2008:197). That is because the sentence has already had a subject, but if the subject is special, then it should be mentioned. 
In addition, the demonstrative reference found in the texts of ABY II books is the word ذللك. It is discovered in the sentence لم تمارس زينب الرياضة ور غم ذلك ظلت نحيفة. Within that example, the pronoun ذلك anaphorically refers to the previous sentence. Meanwhile, the comparative reference found in the book compares words and sentences.

\section{Substitution Devices in Qira'at Text of ABY II Book}

Two types of substitutions were identified in the discourse texts of the ABY II book, namely nominal and clause substitution. The nominal substitution was found in the example presented below.

$$
\text { يعيش في المدن الكبيرة. منل طوكيو ، ولندن، ونيويورك و القاهرة }
$$

The sentence المدن الكبيرة (big cities) is explained in details in the next sentence by mentioning the cities names, such as Tokyo, London, Newyork, and Egypt. Those cities are considered substantial since a large number of domestic and international tourists visit them. Mesir. Meanwhile, clause substitution is discovered in the sentence presented below.

$$
\text { في الحياة الزوجية خير كثير للزوجة وللأو لاد. ومع ذللك تظهر ... }
$$

The phrase ذلك, in the above sentence, functions as an anaphoric substitute of the clause في الحياة الزوجية and so forth. The meaning of the aforementioned sentence is that family life carries a positive effect on wives and children, yet it may also lead to problems. Thus, the writer uses that substitution to create a coherent discourse.

\section{Ellipsis Devices in Qira'at Text of ABY II Book}

Ellipsis or removal is one of the grammatical cohesion types that removes a particular lingual unit that has been stated before (Wiyanti, 2016: 193). Within the ABY II book, three types of ellipsis devices were identified, namely nominal, verbal, and clause ellipsis.

The presence of ellipsis in the discourse texts of the ABY II book is related to the context. Context refers to the internal aspects of a text and all elements that cover the text. Generally, context is divided into language and non-language contexts. The language context is frequently referred to as context, while the non-language context is known as situational and cultural context. The comprehension of the situational or cultural context of a text can be obtained through various interpretations and analogy principles (Wiyanti, 2016: 193). Sumarlan (2003: 48-51) mentions that those principles are personal interpretation, locational interpretation, temporal interpretation, and analogy interpretation principles.

\section{Conjunction Devices in Qira'at Text of ABY II Book}

A conjunction is a word that associates words, phrases, clauses, sentences, or paragraphs. The example of conjunction that connects words and phrases are so that, and, or, for, when, since, before, meanwhile, but, because, with, if, then, as well as that. The example of conjunction that relates paragraphs is in addition, besides, and as for (Rusminto, 2009: 33). 
The conjunction devices found in the ABY II book are temporal, causal, additive, and adversative. Therefore, discourse text requires a conjunction to connect words, phrases, clauses, and sentences. In Arabic, the conjunction is known as Athof. Athof is the type of tawabi (following) after the athhof (conjunction) word that connects isim (noun) or fi'il (verb) (Masiv, 2013).

Similar to conjunction in Indonesian, athof connects words in a sentence, as well as connects sentences and paragraphs. By using athof, the language units are combined into an integrated grammatical unity. Besides, it also creates a diversified meaning. That variation of meaning reflects distinct messages and issues in human lives, as the language user (Masiv, 2013).

Book and or textbook is essential in Arabic teaching and learning. As stated by (Tajuddin et al., 2020; Thohir et al., 2020) that one of the urgent sources in the process of language learning activities is a textbook as a mandatory handbook for teachers and students. Fauzi \& Zakiyah (2021) add that in this multidiscipline era, the integrationinterconnection paradigm is undeniable, including in the textbook. One of the efforts to realize Arabic learning, which contains the value of integration-interconnection, is compiling Arabic textbooks with integration-interconnection values.

\section{E. Conclusion}

According to the analysis and explanation discussed before, it can be concluded that: The reverential devices type in qira'at texts of the ABY II book is personal, demonstrative, and comparative. The personal reference is in the third person singular (mufrad), dual (mutsanna), or plural. At the same time, the demonstrative devices used are the word and the found comparative device is the word that compares sentences. The substitution devices identified in the qira'at text of the ABY II book are nominal and clause substitution. The ellipsis devices discovered in the qira'at text of the ABY II book are nominal, verbal, and clause ellipsis. The conjunction devices found in the qira'at texts of the ABY II book are temporal, causal, additive, and adversative.

Based on the aforementioned results, some suggestions are generated. First, the lecturer of qira'ah muwasa'ah course should consider the cohesion and coherence of the text, besides its nahwu and sharf (morphology). Second, future researchers are expected to conduct a similar study on the coherence aspect.

\section{BIBLIOGRAPHY}

Aflahah. (2012). Kohesi dan Koherensi dalam Wacana. Okara: Jurnal bahasa dan Sastra. 6(1).

Aimahan, U.. (2016). Kohesi Dan Koherensi Bacaan Teks Bahasa Arab Kemenag Kelas X MA

Serta Impilikasinya Terhadap Pembelajaran Bahasa Arab. Thesis UIN Sunan Kalijaga.

Alwi, H. et.al. (2003). Telaah Bahasa dan Sastra. Yayasan Obor Indonesia. 
Bogdan, R.C., \& Biklen, S.B. (1982). Qualitative Research for Education: An Introduction to Theory and Methods. Allyn and Bacon.

Fauzi, M. S., \& Zakiyah, Z. (2021). The Values of Integration-Interconnection in the Material of Arabic Textbook for Islamic Senior High School in Indonesia. Al-Ta'rib: Jurnal Ilmiah Program Studi Pendidikan Bahasa Arab IAIN Palangka Raya, 9(1), 67-84

Halliday, M.A.K .\& Hasan, R. (1976). Cohession In English. Longman Group Limited.

Kridalaksana, H.. (2008). Kamus Linguistik. P.T. Gramedia Pustaka Utama.

Masiv, L. (2013). Sintaksis - Athof-Kata Penghubung Bahasa Arab. Online http://lylamasiv.blogspot.com/2013/05/sintaksis-athof-kata-penghubung-bahasa.html

Miles, M. B., Huberman, A. M., \& Saldana, J. (2014). Qualitative Data Analysis: A Methods Sourcebook. SAGE Publications

Moeliono, A. (1988). Pengembangan dan Pembinaan Bahasa: Ancangan Alternatif di dalam Perencanaan Bahasa. Djambatan.

Moleong, J. L. (1998). Penelitian Kualitatif. Rosdakarya

Mulyana. (2005). Kajian Wacana: Teori, Metode dan Aplikasi Prinsip-prinsip Analisis Wacana. Tiara Wacana.

Soeparno. (2002). Dasar-dasar Linguistik Umum. Tri Wacana.

Suharso. (2011). Kamus Besar Bahasa Indonesia Lengkap. Widya Karya.

Tajuddin, S., Hakim, M. K. A., \& Barnabas, R. A. (2020). Developing Arabic Textbook Material for Junior High School Students. ALSINATUNA, 5(2), 130-146. https://doi.org/10.28918/alsinatuna.v5i2.2322.

Thohir, M., Kurjum, M., \& Muhid, A. (2020). Design and discourse of modern standard Arabic e-textbook. LITERA-Jurnal Penelitian Bahasa, Sastra, Dan Pengajarannya, 19(1), 1-20.

Wiyanti, E. (2016). Kajian Kohesi Gramatikal Substitusi dan Elipsis dalam Novel "Laskar Pelangi" Karya Andera Hirata. Jurnal Pendidikan Bahasa dan Sastra, 16(2), 2016.

Zulaiha, W. P. (2014). Analisis Kohesi Gramatikal dan Leksikal dalam Novel Jemini Karya Suparto Brata. Jurnal Program Studi Pendidikan Bahasa Jawa. 5(1), 2014. 